\title{
Container Throughput Dynamics in the East Asian Container Port System
}

\author{
Theo Notteboom*
}

\begin{abstract}
This paper analyses container throughput developments in the East Asia container port system. Throughput evolutions and concentration/deconcentration patterns in the multi-range container port system of East Asia are analysed. The paper also provides a more in-depth qualitative analysis of the reasons underlying the observed trends and results. It is demonstrated that the East Asian port system is undergoing major structural shifts in cargo patterns and is witnessing a cargo deconcentration trend as a result of the rise of the Chinese ports and the relative stagnation of the Japanese range.
\end{abstract}

Keywords: Container Post System, Cargo patterns

\section{INTRODUCTION}

Seaports function as important nodes in container service networks on the seaside as well as the landside. Cargo volumes on specific trade routes are accommodated by groups of container ports on either side of the route. The spatial development of and competitive forces among these groups of ports (the port systems) reflect the routing preferences of shippers, forwarders and shipping lines. Market dynamics can lead to a port system

Submission Date: 1/20/2006 Acceptance Date: 5/17/2006

* Corresponding Author: Associate Professor, Institute of Transport and Maritime Management, University of Antwerp, Keizerstraat 64, 2000 Antwerp (Belgium), Tel: +32 3 2755149, fax: +32 3 2755150, E-mail: theo.notteboom@ua.ac.be 
characterised by a high dispersion of cargo over many ports or alternatively to a port system with an elevated cargo concentration level.

Much literature addresses the spatial development of seaport systems in relation to maritime and hinterland networks (see e.g. Taaffe et al., 1963, Hayuth, 1981, Barke, 1986, Kuby \& Reid, 1992, Notteboom, 1997, McCalla, 1999, Lago et al., 2001, De \& Park, 2004 and Notteboom \& Rodrigue, 2005). This paper analyses container throughput dynamics in East Asia. The first part provides an empirical overview of the evolution of container throughputs in East Asian ports. The second section zooms in on cargo concentration patterns based on Gini coefficients and their components. The last part of the paper gives a more qualitative insight in the obtained cargo concentration results and puts forward some likely developments for the future.

\section{THE EAST ASIAN CONTAINER PORT SYSTEM}

For most of the past quarter century, no region of the world has been more economically dynamic than East Asia. The unprecedented economic growth of East Asia transformed the patterns of world trade. Especially China now attracts a lot of international attention. China achieved an average GDP growth of $9 \%$, which it has been able to maintain since 1979. In 2003 GDP growth reached 9.1\%, in 2005 9.8\%. Apart from strong growth in domestic consumption, import and export volumes increased by 35 to $40 \%$ per annum in the last five years. China now ranks fourth in the world when it comes to international trade volumes. While China has seen exponential growth, Japan has witnessed a temporary slowdown in economic development. Export-oriented Taiwan and South Korea continue to show healthy growth figures by benefiting from the shifts in economic power in the region and in the world.

The Chinese economic boom, the Japanese setback and the export strategies of Taiwan and South Korea have affected container flows moving in and out the vast East Asian region. Shipping lines are dedicating higher capacities and deploying larger vessels to cope with the increasing East Asian container imports and exports, especially in relation to the China-Europe trade. The East Asian port system is earmarked by remarkable growth and has dramatically changed the ranking of the world's largest container ports. Nine of the twenty largest container ports in the world in 2004 are located in East Asia (Table 1). The position of Japanese ports has weakened, while Chinese ports are climbing fast in the listing. 
Table 1. Top 20 container ports in the world

\begin{tabular}{c|c|c|c|c|c|c|c|c}
\hline \multirow{2}{*}{ RANK } & \multicolumn{2}{|c|}{1975} & \multicolumn{2}{|c|}{1985} & \multicolumn{2}{c|}{1995} & \multicolumn{2}{c}{2004} \\
\cline { 2 - 8 } & PORT & mTEU & PORT & mTEU & PORT & mTEU & PORT & mTEU \\
\hline \hline 1 & Rotterdam & 1.08 & Rotterdam & 2.65 & Hong Kong & 12.55 & Hong Kong & 21.93 \\
2 & New York/NJ & 0.95 & New York/NJ & 2.37 & Singapore & 11.85 & Singapore & 21.33 \\
3 & Kobe & 0.90 & Hong Kong & 2.29 & Kaohsiung & 5.23 & Shanghai & 14.55 \\
4 & Hong Kong & 0.80 & Kobe & 1.52 & Rotterdam & 4.79 & Shenzhen & 13.66 \\
5 & Keelung & 0.56 & Antwerp & 1.35 & Busan & 4.50 & Busna & 11.43 \\
6 & Oakland & 0.52 & Yokohama & 1.33 & Hamburg & 2.89 & Kaohsiung & 9.71 \\
7 & Seattle & 0.48 & Hamburg & 1.16 & Yokohama & 2.76 & Rotterdam & 8.22 \\
8 & Bremerhaven & 0.41 & Keelung & 1.16 & Los Angeles & 2.56 & Los Angeles & 7.32 \\
9 & Long Beach & 0.39 & Busan & 1.15 & Long Beach & 2.39 & Hamburg & 7.00 \\
10 & Melbourne & 0.36 & Long Beach & 1.14 & Antwerp & 2.33 & Dubai & 6.42 \\
11 & Tokyo & 0.36 & Los Angeles & 1.10 & New York/NJ & 2.28 & Antwerp & 6.06 \\
12 & Antwerp & 0.36 & Tokyo & 1.00 & Tokyo & 2.18 & Long Beach & 5.78 \\
13 & Yokohama & 0.33 & Bremerhaven & 0.99 & Keelung & 2.17 & Port Kelang & 5.24 \\
14 & Hamburg & 0.30 & San Juan & 0.88 & Dubai & 2.07 & Qingdao & 5.14 \\
15 & Sydney Harbour & 0.26 & Oakland & 0.86 & Felixstowe & 1.90 & New York/NJ & 4.47 \\
16 & San Juan & 0.26 & Seattle & 0.85 & Manila & 1.67 & Tanjung Pelepas & 4.02 \\
17 & Tilbury & 0.23 & Bremerhaven & 0.83 & San Juan & 1.59 & Ningbo & 4.01 \\
18 & Le Harvre & 0.23 & Dunkirk & 0.71 & Oakland & 1.55 & Tianjin & 3.81 \\
19 & Kaohsiung & 0.23 & Baltimore & 0.71 & Shanghai & 1.53 & Leam Chabang & 3.62 \\
20 & Jacksonville & 0.21 & Jeddah & 0.68 & Bremerhaven & 1.53 & Tokyo & 3.58 \\
\hline
\end{tabular}

Source: Containerisation International - CI Online Note: East Asia ports in bold

Figure 1. The East Asian port system and port ranges

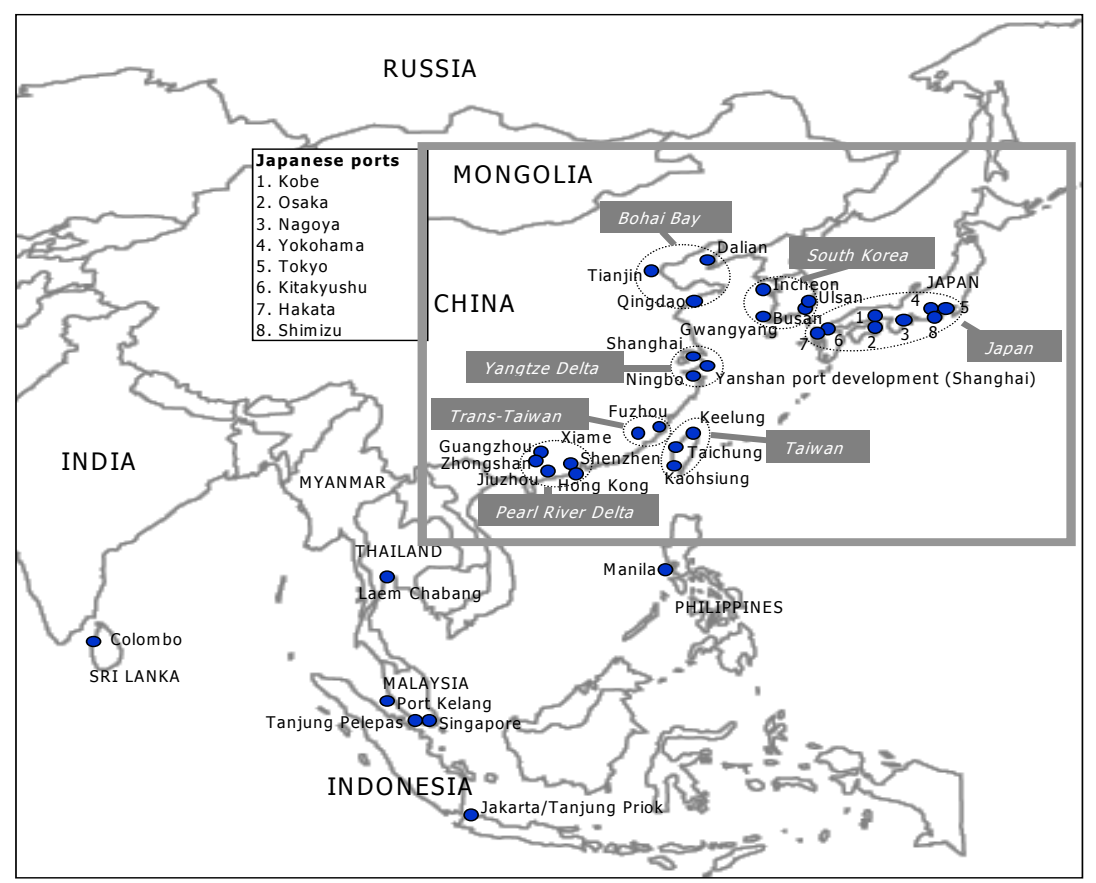


The East Asian container port system is a heterogeneous blend of subsystems or port ranges and individual ports, each with different characteristics with respect to cargo flows, cargo balance, commodity specialization, hinterland coverage, physical lay-out, port management system, etc.. The East Asian container port system as considered in this paper consists of 27 container ports divided over seven port ranges (see Figure 1). Container traffic data in TEU for the period 1978-2004 were collected from the respective port authorities and Containerisation International Online.

Total container throughput in the seven East Asian ranges evolved from 5.7 million TEU in 1978 to 114 million TEU in 2004. It can be observed the Chinese port ranges are gaining in importance after decades of moderate growth (Figure 2). In 1992, the Pearl River Delta surpassed the Japanese port system to become the most important range in East Asia. Also the Yangtze Delta range is rapidly becoming a strong cargo concentration point in the East Asian container port system.

Figure 3 provides more insight in the evolution of the relative positions of the observed ranges for three-year periods, starting from 1980-1983 till 2001-2004. At present, the average container growth in the Japanese port system is as low as in the early days of containerisation (around half a million TEU per year). Its market share declined dramatically from $43 \%$ in the early 1980 s to only $12 \%$ in 2004 . The Japanese range was recently passed by the Yangtze Delta and the South Korean range, making it today only the fourth largest range. It is expected that the Taiwan range and the Bohai Bay range will overtake the Japanese range in the next couple of years.

Figure 2. Container traffic for given port ranges (in million TEU, 1978-2004)

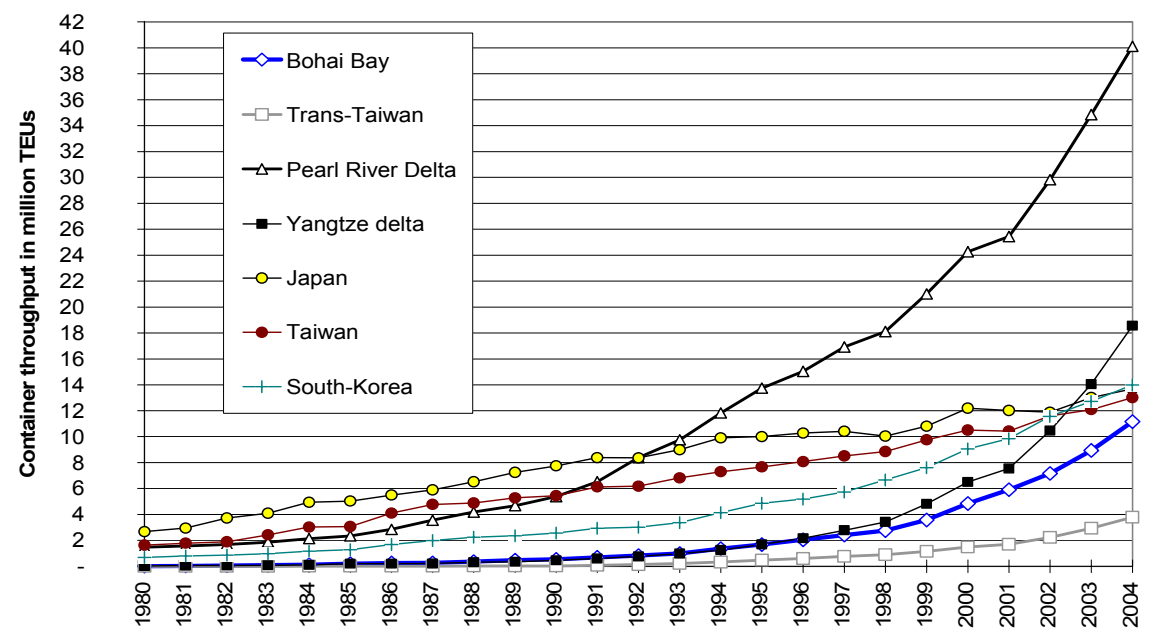


Figure 3. A dynamic positioning of port ranges based on market share and TEU growth

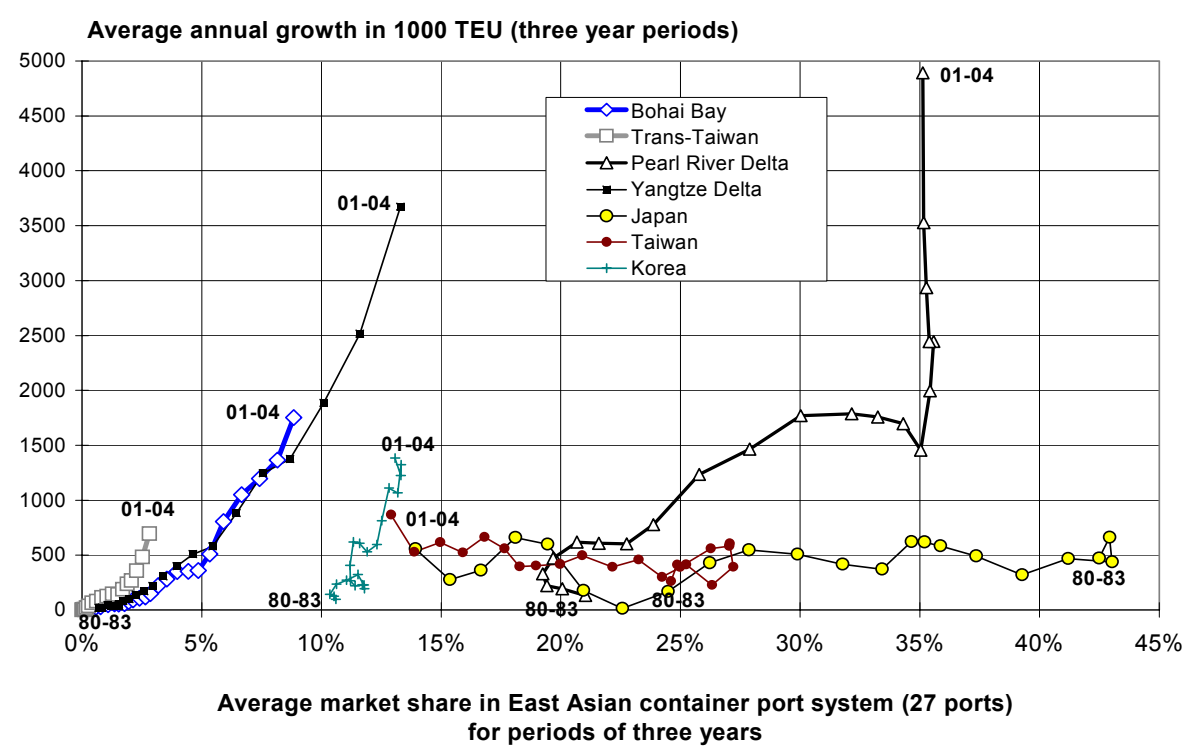

The market share of the Pearl River Delta range stabilized at around 35\% (after years of strong increase), while absolute annual growth figures now exceed 5 million TEU. Even more spectacular is the steep rise of the Yangtze Delta and the other smaller ranges in China. Only twenty years ago the Chinese container port system was still in its infancy stage. Hong Kong acted as the only container gateway to China handling more than 2 million TEU in 1985, whereas all mainland container ports together only handled 0.2 million TEU in the same year. Since the second half of the 1990s container throughput at mainland ports started to accelerate. In the period 1995-1998 container traffic at the main Chinese container ports doubled to reach almost 10 million TEU in 1998. In 2003 the Chinese container port system (excluding Hong Kong) handled four times more compared to 1998. The main container ports, at present, are Shanghai, Tianjin, Dalian, Qingdao, Shenzhen, Ningbo, Guangzhou and Xiamen. In 2004, the ports of Shanghai and Shenzhen reached a throughput figure of more than 13 million TEU, thereby narrowing the throughput gap with Hong Kong. Shenzhen port in South China's Guangdong Province has seen the fastest growth in the past years, taking the second place among Chinese container ports for six successive years. The rise of individual Chinese container 
ports is depicted in Table 2. The dominance of Hong Kong is eroding as ports from mainland China are moving up.

Table 2. Top 15 container ports in East Asia

\begin{tabular}{|c|c|c|c|c|c|c|c|c|c|c|c|c|c|c|c|}
\hline & \multicolumn{3}{|c|}{1978} & \multicolumn{3}{|c|}{1985} & \multicolumn{3}{|c|}{1995} & \multicolumn{3}{|c|}{2000} & \multicolumn{3}{|c|}{2004} \\
\hline & & $1000 \mathrm{TEU}$ & $\%$ & & $1000 \mathrm{TEU}$ & $\%$ & & $1000 \mathrm{TEU}$ & $\%$ & & 1000 TEU & $\%$ & & 1000 TEU & $\%$ \\
\hline 1 & Kobe & 1447 & $25.4 \%$ & Hong Kong & 2289 & $18.8 \%$ & Hong Kong & 12550 & $31.3 \%$ & Hong Kong & 18098 & $26.3 \%$ & Hong Kong & 21930 & $19.2 \%$ \\
\hline 2 & Hong Kong & 1226 & $21.5 \%$ & Kaohsiung & 1901 & $15.6 \%$ & Kaohsiung & 5053 & $12.6 \%$ & Busan & 7540 & $10.9 \%$ & Shanghai & 14557 & $12.7 \%$ \\
\hline 3 & Kaohsiung & 570 & $10.0 \%$ & Kobe & 1519 & $12.5 \%$ & Busan & 4503 & $11.2 \%$ & Kaohsiung & 7426 & $10.8 \%$ & Shenzhen & 13660 & $11.9 \%$ \\
\hline 4 & Tokyo & 551 & $9.7 \%$ & Yokohama & 1327 & $10.9 \%$ & Yokohama & 2727 & $6.8 \%$ & Shanghai & 5612 & $8.1 \%$ & Busan & 11430 & $10.0 \%$ \\
\hline 5 & Busan & 507 & $8.9 \%$ & Keelung & 1158 & $9.5 \%$ & Tokyo & 2177 & $5.4 \%$ & Shenzhen & 3994 & $5.8 \%$ & Kaohsiung & 9710 & $8.5 \%$ \\
\hline 6 & Yokohama & 500 & $8.8 \%$ & Busan & 1155 & $9.5 \%$ & Keelung & 2170 & $5.4 \%$ & Tokyo & 2899 & $4.2 \%$ & Qingdao & 5140 & $4.5 \%$ \\
\hline 7 & Keelung & 474 & $8.3 \%$ & Tokyo & 1004 & $8.3 \%$ & Shanghai & 1527 & $3.8 \%$ & Yokohama & 2317 & $3.4 \%$ & Ningbo & 4006 & $3.5 \%$ \\
\hline 8 & Nagoya & 170 & $3.0 \%$ & Osaka & 423 & $3.5 \%$ & Nagoya & 1477 & $3.7 \%$ & Kobe & 2266 & $3.3 \%$ & Tianjin & 3814 & $3.3 \%$ \\
\hline 9 & Osaka & 149 & $2.6 \%$ & Nagoya & 422 & $3.5 \%$ & Kobe & 1464 & $3.6 \%$ & Qingdao & 2120 & $3.1 \%$ & Tokyo & 3358 & $2.9 \%$ \\
\hline 10 & Incheon & 48 & $0.8 \%$ & Shanghai & 202 & $1.7 \%$ & Osaka & 1159 & $2.9 \%$ & Keelung & 1955 & $2.8 \%$ & Guangzhou & 3308 & $2.9 \%$ \\
\hline 11 & Shimizu & 34 & $0.6 \%$ & Kitakyushu & 161 & $1.3 \%$ & Tianjin & 702 & $1.7 \%$ & Nagoya & 1912 & $2.8 \%$ & Xiamen & 2872 & $2.5 \%$ \\
\hline 12 & Shanghai & 15 & $0.3 \%$ & Tianjin & 148 & $1.2 \%$ & Qingdao & 603 & $1.5 \%$ & Tianjin & 1708 & $2.5 \%$ & Yokohama & 2718 & $2.4 \%$ \\
\hline 13 & Taichung & 2 & $0.0 \%$ & Incheon & 131 & $1.1 \%$ & Guangzhou & 515 & $1.3 \%$ & Osaka & 1474 & $2.1 \%$ & Dalian & 2211 & $1.9 \%$ \\
\hline 14 & & & $0.0 \%$ & Shimizu & 128 & $1.1 \%$ & Kitakyushu & 449 & $1.1 \%$ & Guangzhou & 1430 & $2.1 \%$ & Kobe & 2180 & $1.9 \%$ \\
\hline 15 & & & $0.0 \%$ & Hakata & 60 & $0.5 \%$ & Taichung & 447 & $1.1 \%$ & Taichung & 1130 & $1.6 \%$ & Nagoya & 2155 & $1.9 \%$ \\
\hline & Top 5 & 4300 & $75.6 \%$ & Top 5 & 8194 & $67.3 \%$ & Top 5 & 27010 & $67.3 \%$ & Top 5 & 42670 & $62.0 \%$ & Top 5 & 71287 & $62.3 \%$ \\
\hline & Top 10 & 5640 & $99.1 \%$ & Top 10 & 11400 & $93.6 \%$ & Top 10 & 34806 & $86.7 \%$ & Top 10 & 54227 & $78.7 \%$ & Top 10 & 90913 & $79.5 \%$ \\
\hline & \begin{tabular}{|l|} 
Top 15 \\
\end{tabular} & 5691 & $100.0 \%$ & Top 15 & 12027 & $98.8 \%$ & Top 15 & 37522 & $93.5 \%$ & Top 15 & 61881 & $89.8 \%$ & Top 15 & 103049 & $90.1 \%$ \\
\hline & $\begin{array}{l}\text { TOTAL } \\
\text { (27 ports) }\end{array}$ & 5691 & $100 \%$ & $\begin{array}{l}\text { TOTAL } \\
\text { (27 ports) }\end{array}$ & 12173 & $100 \%$ & \begin{tabular}{|l} 
TOTAL \\
(27 ports)
\end{tabular} & 40132 & $100 \%$ & \begin{tabular}{|l} 
TOTAL \\
(27 ports)
\end{tabular} & 68878 & $100 \%$ & \begin{tabular}{|l|} 
TOTAL \\
(27 ports)
\end{tabular} & 114349 & $100 \%$ \\
\hline
\end{tabular}

\section{CONCENTRATION PATTERNS IN THE EAST ASIAN CONTAINER PORT SYSTEM}

Transport geographers often deploy Gini coefficients as a method to measuring traffic concentration at transportation nodes such as airports, intermodal terminals and seaports. If all the ports in a port system are of equal size, the Gini coefficient will equal zero. In case one port accounts for the total volume of containers, the Gini coefficient equals unity. The Gini coefficient has previously been successfully applied to the US general cargo port system (Kuby and Reid, 1992), the US container port system (Hayuth, 1988, McCalla, 1999 and Lago et al., 2001), the world port system (De \& Park, 2004) and the European container port system (Notteboom, 1997). The Gini coefficients for the East Asian container port system and its ranges are given in Figure 4. 
Figure 4. Evolution of the Gini coefficients for port system and individual ranges

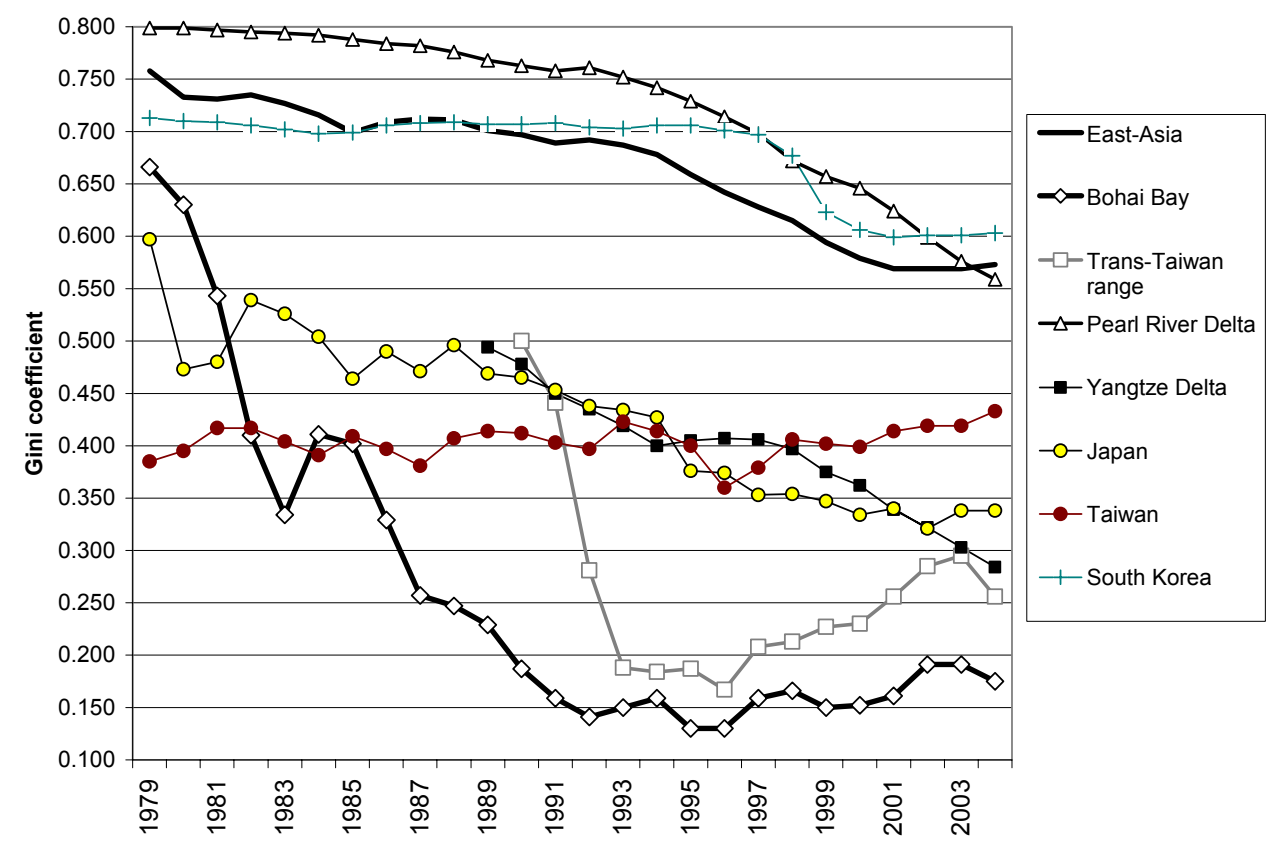

The port system as a whole shows a clear trend towards a less concentrated system, although the Gini coefficient levelled out in the last few years. The Pearl River Delta has the highest concentration ratio of all ranges. The intense competition Hong Kong is facing from mainland Chinese ports such as Shenzhen and Guangzhou has dramatically decreased the inequality in the range. The South Korean load centre group witnessed a similar evolution, mainly triggered by the development of the port of Gwangyang in the late 1990s to form a twin-hub system with main port Busan. The Bohai bay ports do not substantially differ in size and have a similar growth pattern, so concentration levels are very low. The sharp decline of the Gini coefficient in the 1980s was caused by the start of container operations in Qingdao and Dalian to challenge market leader Tianjin. Also the Japanese port system is becoming more evenly distributed. Kobe, Tokyo and Yokohama accounted for most of the container traffic for years. However, Kobe never recovered fully from the earthquake that hit the city in 1995: container throughput abruptly fell from 2.9 million TEU in 1994 to 1.46 in 1995 and today volumes are about 2.2 million TEU. Another factor contributing to falling Gini coefficients relates to Nagoya and Osaka 
playing a more significant role in the Japanese container scene. Concentration levels in the Taiwanese port range fluctuated slightly over time. In the last couple of years the Gini coefficient is rising, an observation that mirrors the stagnation of throughput levels in Keelung combined with strong growth in Kaohsiung.

The literature provides some techniques to decompose the Gini coefficient neatly into a weighted sum of within and between group inequality. Dagum (1997) has shown how the Gini inequality index can be additively decomposed into the weighted sum of three components: (i) the Gini inequality within the subpopulations, (ii) the Gini inequality between subpopulations net of transvariation (the so-called overlapping effects between groups or subpopulations) and (iii) the intensity of transvariation between groups.

Applied to ports, the Gini coefficient for the total container port system decomposed in three components can be written as $G=G_{w}+G_{b}+G_{t}$. The first component $\mathrm{G}_{\mathrm{w}}$ is the inequality within port ranges. It can be computed as a weighted average of the ranges' Gini coefficients.

The second component $\mathrm{Gb}$ is the inequality between port ranges. It can best be interpreted as the between-range Gini coefficient obtained if every port throughput in every range were to be replaced by the relevant range mean. The third component is formed by the transvariation or the overlapping effects between port ranges. A customised version of the Gini decomposition software developed by Mussard et al (2003) was used to obtain results for the three components of the decomposition exercise ( $\mathrm{Gb}$, Gw and $\mathrm{Gt}$ ).

Figure 5. Gini decomposition analysis for the East Asian port system (relative shares of $\mathrm{G}_{\mathrm{w}}, \mathrm{G}_{\mathrm{b}}$ and $\mathrm{G}_{\mathrm{t}}$ )

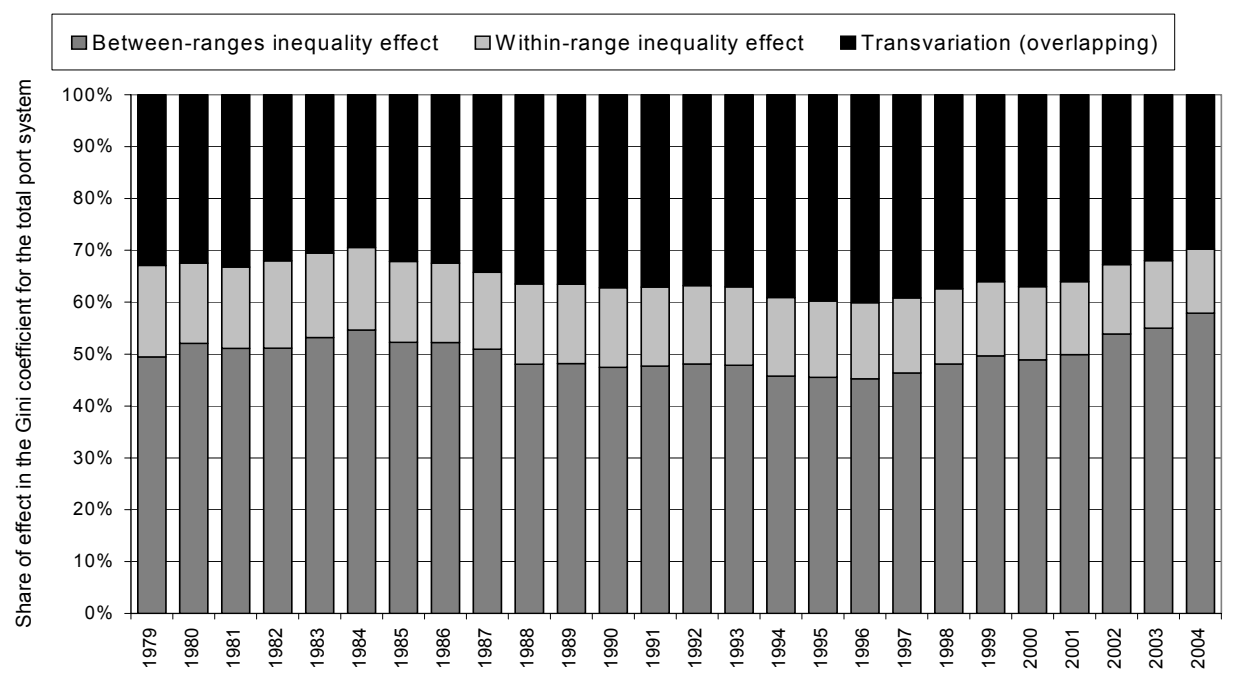


The results in Figure 5 lead to the following conclusions with respect to the Gini decomposition exercise. The East Asian container port system shows a moderate shift from within-range inequality to between-range inequality effects, in particular since the new millennium. The share of the within-range inequality component amounted to $12.3 \%$ in 2004, the lowest share ever. The weight of the between-range inequality reached $58 \%$.

Figure 6. Detailed Gini decomposition for the East Asian port system (contribution of $\mathrm{G}_{\mathrm{w}}, \mathrm{G}_{\mathrm{b}}$ and $\mathrm{G}_{\mathrm{t}}$ in absolute terms)

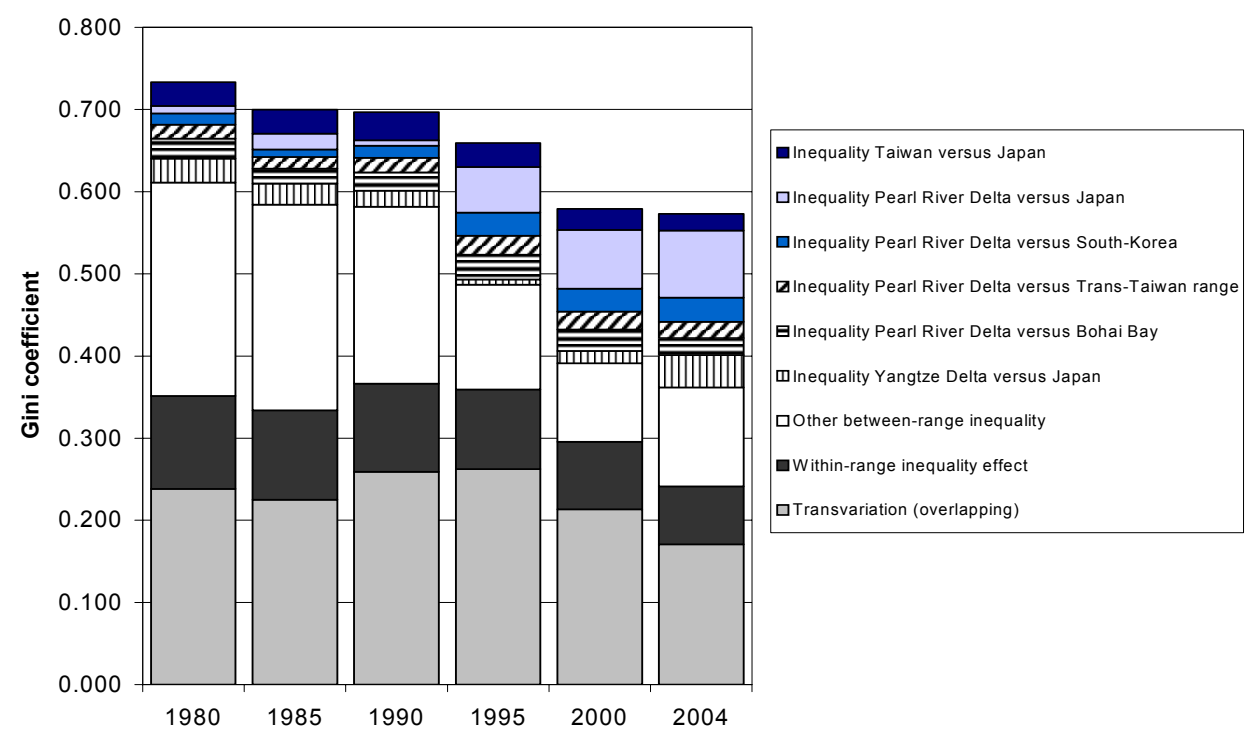

Table 3. Selected between-range Gini indexes $\left(\mathrm{G}_{\mathrm{jh}}\right)$

\begin{tabular}{c|c}
\hline Gjh & $\begin{array}{c}\text { East Asian port system } \\
\text { Pearl River Delta vs. } \\
\text { Japanese range }\end{array}$ \\
\hline \hline 1980 & 0.784 \\
1985 & 0.750 \\
1990 & 0.757 \\
1995 & 0.763 \\
2000 & 0.697 \\
2001 & 0.698 \\
2002 & 0.721 \\
2003 & 0.733 \\
2004 & 0.746 \\
\hline
\end{tabular}


The relatively high inequality between the Pearl River Delta range and the Japanese range is having an ever larger share in the total Gini coefficient (Figure 6 and Table 3). At the same time, the relative importance of other between-range inequalities is decreasing, thereby contributing to a decline in the overall Gini coefficient for the East Asian container port system (as earlier depicted in Figure 4).

Table 4. Contribution of the inequality between the Pearl River Delta and the Japanase range to the total Gini $G$ and the between-ranges Gini $G_{b}$

\begin{tabular}{c|c|c|c|c|c|c}
\hline & $\begin{array}{c}\mathrm{G} \\
(1)\end{array}$ & $\begin{array}{c}\mathrm{G}_{\mathrm{b}} \\
(2)\end{array}$ & $\begin{array}{c}\mathrm{G}_{\mathrm{jh}} \mathrm{D}_{\mathrm{jh}}\left(\mathrm{p}_{\mathrm{j} S \mathrm{~S}}+\mathrm{p}_{\mathrm{h}} \mathrm{S}_{\mathrm{j}}\right) \\
(3)\end{array}$ & $\begin{array}{c}\text { Ratio } \\
(2) /(1)\end{array}$ & $\begin{array}{c}\text { Ratio } \\
(3) /(1)\end{array}$ & $\begin{array}{c}\text { Ratio } \\
(3) /(2)\end{array}$ \\
\hline \hline 1980 & 0.733 & 0.382 & 0.009 & $52 \%$ & $1.3 \%$ & $2.4 \%$ \\
1985 & 0.700 & 0.366 & 0.020 & $52 \%$ & $2.8 \%$ & $5.4 \%$ \\
1990 & 0.697 & 0.331 & 0.007 & $47 \%$ & $1.0 \%$ & $2.1 \%$ \\
1995 & 0.659 & 0.300 & 0.055 & $46 \%$ & $8.4 \%$ & $18.4 \%$ \\
2000 & 0.580 & 0.284 & 0.072 & $49 \%$ & $12.3 \%$ & $25.2 \%$ \\
2001 & 0.569 & 0.284 & 0.073 & $50 \%$ & $12.8 \%$ & $25.6 \%$ \\
2002 & 0.568 & 0.306 & 0.078 & $54 \%$ & $13.8 \%$ & $25.6 \%$ \\
2003 & 0.569 & 0.313 & 0.080 & $55 \%$ & $14.1 \%$ & $25.6 \%$ \\
2004 & 0.573 & 0.332 & 0.082 & $58 \%$ & $14.3 \%$ & $24.6 \%$ \\
\hline
\end{tabular}

The inequality between the Pearl River Delta and the Japanese range (i.e. the between-range index $G_{j h}$ in table 3) to a large extent is responsible for the relative explanatory power of $\mathrm{G}_{\mathrm{b}}$. In 1980 the net contribution of $\mathrm{G}_{\mathrm{jh}}$ for the observed port range pair still amounted to a very low 0.009 or $1.3 \%$ of the Gini ratio for the entire port system (see ratio (3)/(1) in Table 4). By 2004 this share had increased to more than 14\%, thereby contributing to the observed increase in the ratio $\mathrm{G}_{\mathrm{b}} / \mathrm{G}$.

$\mathrm{D}_{\mathrm{jh}}$ in column 4 of table 4 is a normalized index that indicates the 'distance' between port ranges $P_{j}$ and $P_{h}$ (see Dagum (1980) for a more in-depth discussion of this index). The term distance is not to be interpreted as the physical distance (e.g. in nautical miles), but as a measure of the structural differences between the subgroups' structures.

\section{A QUALITATIVE ANALYSIS}

The last section in this paper provides a more in-depth qualitative analysis of the factors underlying observed concentration and deconcentration trends in the East Asian container port system, with a special focus on Chinese load centres. 


\subsection{The Dynamics in Liner Service Networks}

Shipping lines and ports are constantly redesigning their service networks and terminal operations in order to cope with the increased flows. The hierarchy among the ports in the East Asian container port system is being challenged by the strong growth of smaller container ports and the outspoken hub ambitions of many large ports.

The recent strong growth of the ports of mainland China introduced a new dynamic in the East Asian container port system. Robinson (1998) showed that the liner shipping networks in East Asia evolved from a complex set of feeder services connected to the major hubs in the 1980s into a hierarchy of liner networks with high cost/high efficiency hubs in the higher order networks and a mix of hub and direct-call ports in the lower order networks. The highest order ports identified were Hong Kong, Kaohsiung and Busan. Hong Kong served as the load center for the Pearl River Delta with substantial amount of containers moving through the port originating from or was destined for its immediate hinterland in the Guangdong province in China. For Kaohsiung, strong export-led growth of the Taiwanese economy enabled the port to become a major hub and the authorization of cross-straits shipping is expected to further boost container handling at the port. For Busan, considered a load center for South Korea, cost-competitive and -efficient strategies pursued by the port initially attracted a lot of Chinese and Japanese containers to be transshipped through the port (Fleming, 1997). Busan was thus able to expand its hinterland beyond South Korea into Northeast Asia. Fleming also noted that as late as the mid-1990s, all of China was served by feeder services through Hong Kong or Japanese ports while Busan and Kaohsiung were newcomers to the scene to vie for Chinese container traffic.

The above demonstrates Hong Kong, Busan and Kaohsiung have long dominated container handling in East Asia. This development corresponded with the boom in external trade that resulted from successful export-oriented economic strategies pursued by Hong Kong, Taiwan and South Korea. Container flows to and from Northeast China relied on connections to the main hubs in order to reach the global markets.

From the 1990s, however, the gradual shift in the gravity of economic growth and trade from Japan to China led to the emergence of new gateway ports such as Shanghai and Shenzhen. The incumbents now also face the prospect of intensified competition from other potential candidates, including some emerging North-Eastern ports vying for a greater share of container traffic in East Asia. 
The main ports of North-Eastern China include five ports: Dalian, Qingdao, Tianjin, Shanghai and Ningbo. Dalian plays a very important role in terms of shipping grain and oil produced in the Northern provinces. Qingdao is a diversified port, dealing with bulk, oil, container, vegetables and sea products. Forty per cent of the vegetables consumed in South Korea come from China via the Qingdao port. The Tianjin port excels in bulk shipping and container shipping and can rely on its advanced distribution system with excellent access to its hinterlands. Shanghai and Ningbo mainly put their developing emphasis on container shipping, especially cargoes shipped from the Yangtze River to the sea. The hinterlands of those five ports are huge and cover above $70 \%$ of China in terms of area, population, gross domestic product and waterway freight traffic. The value of imports and exports also takes up more than half of the total value of China (Guo \& Notteboom, 2004).

The hinterland of Dalian mainly consists of the three provinces of North China, namely Heilongjang, Jilin and Liaoning, which are the main grain and heavy industry provinces of China. About $85 \%$ of maritime cargoes of these three provinces are transported by Dalian port. The Qingdao port is the most important port in Shandong province. With the strong economic development of Shandong province, Qingdao port gets the opportunity to develop, as $90 \%$ of maritime cargo flows of the Shandong province are shipped via the Qingdao port. Meanwhile, the Qingdao port is also striving to attract some cargo from the northern provinces. The Tianjin port has the whole middle part of China as its hinterland, ranging from north-east to the north-west, especially the capital city Beijing. The hinterlands of Shanghai and Ningbo are more or less overlapping, covering the whole Yangtze Delta and the eastern regions of China.

\subsection{More Direct Calls in the Bohai Bay Region}

In East Asia, concentration within the liner shipping industry allowed shipping lines to reorganize their services to capitalize on the booming Chinese port traffic while at the same time, call directly at more ports in the region. Altogether, mainline services offered by the top twenty shipping lines called at 35 ports in the region in 2001, seven more from 1995 (Yap et al., 2006). These direct calls had the effect of reducing the market share of Japanese and Taiwanese ports while increasing those of Chinese ports (Table 5). The share of South Korean ports, other than Gwangyang, was also reduced. The recent evolution in the slot capacities calling at East Asian ports demonstrates a huge increase in direct calls to Chinese ports in recent years, including the Bohai bay ports. These findings 
are consistent with the recent strong growth in the cargo throughput of the Chinese container port system.

Table 5. Share of Slot Capacity Deployed by Mainline Services at Major Ports in East Asia

\begin{tabular}{c|c|c|c|c|c}
\hline Port & $\begin{array}{c}2001 \\
(\%)\end{array}$ & $\begin{array}{c}\text { Change from } \\
1995(\%)\end{array}$ & Port & $\begin{array}{c}2001 \\
(\%)\end{array}$ & $\begin{array}{c}\text { Change from } \\
1995(\%)\end{array}$ \\
\hline \hline Hong Kong & 89.5 & -0.6 & Xiamen & 12.3 & 12.2 \\
Kaohsiung & 52.5 & -9.3 & Osaka & 11.9 & -11.3 \\
Shenzhen & 49.1 & 40.0 & Ningbo & $\mathbf{1 1 . 6}$ & $\mathbf{1 1 . 6}$ \\
Pusan & 41.2 & -4.6 & Qingdao & $\mathbf{1 0 . 4}$ & $\mathbf{7 . 5}$ \\
Kobe & 33.6 & -8.6 & Keelung & 9.0 & -12.7 \\
Shanghai & $\mathbf{2 8 . 1}$ & $\mathbf{2 0 . 7}$ & Hakata & 8.0 & -3.7 \\
Tokyo & 27.2 & -11.8 & Tianjin & 7.1 & 3.4 \\
Yokohama & 26.6 & -6.9 & Shimizu & 3.8 & -12.4 \\
Nagoya & 25.8 & -13.2 & Dalian & $\mathbf{2 . 4}$ & $\mathbf{- 0 . 4}$ \\
Kwangyang & 12.7 & 12.7 & Naha & 1.8 & 0.4 \\
\hline
\end{tabular}

Source: Yap et al. (2006).

Table 6 summarizes the number of port calls according to the schedules of some leading shipping lines. A large number of shipping lines started or will initiate services with direct port calls in Northeast China mainly thanks to the upsurge in cargo volumes related to that region. It is apparent that Dalian, Qingdao and Tianjin are not located along the world's main shipping lanes, which means the deviation distances to these ports are relatively high compared to the ports of Shanghai and Ningbo. In a situation of low cargo volumes the high deviation distances might impede shipping lines to call directly at these ports with their mainline vessels. However, rising cargo availability and the vast hinterland potential of the three Bohai bay ports now seem to counterbalance the extra shipping costs incurred by the high deviation distance linked to reaching the ports in the Bohai bay. 
Table 6. Number of port calls for each shipping line (number of loops/ number of vessels)

\begin{tabular}{l|c|c|c}
\hline & Dalian & Qingdao & Tianjin \\
\hline \hline Maersk & $6(12)$ & $6(12)$ & $6(12)$ \\
MSC & 0 & $6(24)$ & $6(24)$ \\
Evergreen & $2(6)$ & $4(10)$ & $4(10)$ \\
P\&O Nedllord & $1(4)$ & $2(8)$ & $1(4)$ \\
CMA-CGM & $1(5)$ & $1(5)$ & $1(5)$ \\
Hanjin & $1(3)$ & $4(12)$ & $4(12)$ \\
APL & 0 & $4(20)$ & 0 \\
NYK Line & 0 & $2(6)$ & 0 \\
COSCO & $5(10)$ & $12(24)$ & $4(8)$ \\
China Shipping & $11(22)$ & $13(26)$ & $12(24)$ \\
K-Line & $3(12)$ & $3(12)$ & $5(20)$ \\
OOCL & $1(6)$ & $1(6)$ & $1(6)$ \\
Mitsui O.S.K & 0 & 0 & 0 \\
ZIM ISREAL & $1(3)$ & $1(3)$ & $1(3)$ \\
CCNL & 0 & 0 & 0 \\
Yang Ming Line & $3(6)$ & $2(4)$ & $4(8)$ \\
HMM & $7(28)$ & $8(32)$ & $8(32)$ \\
\hline
\end{tabular}

Source: Compiled from information on http://www.jctrans.com/banqi/ . Data on April 1, 2004. Backhaul not included. COSCO and China Shipping: domestic shipping and feeder calls excluded.

The current nature of mainland Chinese ports points to gateway ports rather than to transhipment hubs. Only $2 \%$ of containers handled in Shanghai relates to sea-sea transhipment. In Hong Kong the transhipment percentage amounts to about $30 \%$, in Busan to around $40 \%$ and in Kaohsiung to about 55\%. The transhipment cargo percentage of the Bohai bay ports are low as well, partly due to the less favourable maritime location for serving the whole of East Asia and the associated high deviation distances. However, it does not imply the Bohai bay ports have a feeder port status. The three Bohai bay ports are strengthening their role as gateway ports to large hinterland regions, even though they do not play a role as sea-sea transhipment centres.

The ports in the Bohai bay are doing everything they can to strengthen their position as direct ports of call, including investing huge amounts of money on new projects to enlarge the port capacity, improving the service level and port efficiency, cooperating with global terminal operators and shipping lines and striving to develop rail, road and other hinterland systems. The near future could see greater vertical and horizontal integration attempts as logistics service providers actively expand on their business scope to capitalize on the economic opportunities presented by China. The Bohai Bay ports place greater emphasis on logistics and intermodal concerns, on capitalizing on economic 
opportunities from China and on exploiting possibilities presented by information and communication technological advancements.

\subsection{Enhancing the Development of Chinese Ports}

To maintain economic expansion, the Chinese government has focused a great deal of its resources on modernizing China's infrastructure. This includes roads, airports and seaports in coastal regions. Seaports have always played a key role in the government's policy with regard to infrastructure provision. In the earlier stage of New China (1970s), port construction began from almost nothing. By 1985, deep-water berths at major coastal ports increased to 198, along with 156 medium-class berths for a combined annual handling capacity of 310 million tons. In the 1990s, construction of ports was a key element in infrastructure development. During the 9th five-year plan period progress has been made in the construction of coastal ports. 133 medium and above classed berths were built, among which 96 are deepwater berths (figures of Ministry of Communications). The Chinese government started to allow foreign businesses to build and operate berths in the form of a joint venture, to engage in the stevedoring business, cargo storage and other related services. These measures have promoted port construction. The hinterland infrastructure still needs further upgrading to prevent the Chinese giant from crumbling on weak (hinterland) legs.

With the accession to the WTO, Chinese ports are opening up to the world. Some world famous companies have already built terminals in Chinese ports, such as Hutchison, CSX World Terminals, PSA Corp, APM Terminals and P\&O Ports. Table 7 lists all the international terminal operators in Chinese ports in June 2002, while Table 8 provides an overview of current container port construction projects in China. 
Table 7. Shareholding structures among selected ports and terminals as of June 2002

\begin{tabular}{|c|c|c|c|}
\hline Region & Port & Container Terminal & Shareholding Structure \\
\hline $\begin{array}{l}\text { Pearl } \\
\text { River } \\
\text { Delta }\end{array}$ & $\begin{array}{l}\text { Guangzhou } \\
\text { Shenzhen }\end{array}$ & $\begin{array}{l}\text { Guangzhou container terminal } \\
\text { Yantian International Container } \\
\text { Terminals } \\
\text { Shekou Container Terminals } \\
\text { Chiwan Container Terminals }\end{array}$ & $\begin{array}{l}\text { PSA } 49 \% \text {, Guangzhou Harbor Bureau } \\
51 \% \\
\text { HPH } 58 \% \text {, Maersk } 10 \% \text {, Yantian Port } \\
\text { Holdings } 27 \% \text {, COSCO Pacific } 5 \% \\
\text { P\&O Ports } 25 \% \text {, Swire } 25 \% \text {, China, } \\
\text { Merchant } 32.5 \% \text {, COSCO } 17.5 \% \\
\text { MTL+China Merchants } 25 \% \text {, Kerry } \\
\text { Logistics } 25 \% \text {, Chiwan Port Holdings } \\
50 \%\end{array}$ \\
\hline $\begin{array}{c}\text { Trans-T } \\
\text { aiwan }\end{array}$ & $\begin{array}{l}\text { Fuzhou } \\
\text { Shantou } \\
\text { Xiamen }\end{array}$ & $\begin{array}{l}\text { Fuzhou Container Terminals } \\
\text { Fuzhou Aofeng Container } \\
\text { Terminals } \\
\text { Shantou International Container } \\
\text { Terminals } \\
\text { Xiamen International Container } \\
\text { Terminals } \\
\text { Xiamen Xianyu Quay Co.Ltd } \\
\text { Xiamen Xianyu Free Trade Zone } \\
\text { Quay Xree Port } \\
\text { Xiamen Xianyu Fren } \\
\text { Development }\end{array}$ & $\begin{array}{l}\text { PSA } 49 \% \text {, Fuzhou Port Authority 51\% } \\
\text { PSA } 49 \% \text {, Fuzhou Port Authority 51\% } \\
\text { HDP } 70 \% \text {, Shantou Port Authority } 30 \% \\
\text { HDP } 49 \% \text {, Xiamen Haicang Ports } 51 \% \\
\text { Pacific Ports } 92 \% \text {, Xiamen Xianyu } \\
\text { Group Corporation } 2 \% \\
\text { Pacific Ports } 60 \% \text {, Xiamen Xianyu } \\
\text { Group Corporation } 40 \% \\
\text { Xiamen Xianyu Group Corportation } \\
100 \%\end{array}$ \\
\hline $\begin{array}{c}\text { Yangtz } \\
\text { e River } \\
\text { Delta }\end{array}$ & Shanghai & $\begin{array}{l}\text { Ningbo Beilun } \\
\text { Terminals Phase I } \\
\text { Ningbo Beilun } \\
\text { Terminals Phase Container } \\
\text { Shanghai Container Terminals } \\
\\
\text { Shanghai Wai Gao Qiao Phase I }\end{array}$ & $\begin{array}{l}\text { Ningbo Port Authority } 100 \% \\
\text { HPH } 49 \% \text {, Ningbo Port Authority } 51 \% \\
\text { HPH } 37 \% \text {, Shanghai Port Container } \\
63 \% \\
\text { HPH } 40 \% \text {, Shanghai Port Authority } \\
30 \% \\
\text { COSCO Pacific } 20 \% \text {,Shanghai Shiye } \\
10 \%\end{array}$ \\
\hline $\begin{array}{c}\text { Bohai } \\
\text { Bay }\end{array}$ & $\begin{array}{l}\text { Dalian } \\
\text { Qingdao }\end{array}$ & $\begin{array}{l}\text { Dalian Container Terminals } \\
\text { Qingdao Qianwan Container } \\
\text { Terminals } \\
\text { Tianjin Sinor Terminals } \\
\text { CSX Orient Container Terminals }\end{array}$ & $\begin{array}{l}\text { PSA+Maersk } 49 \%, \text { Dalian } \\
\text { Authority } 51 \% \\
\text { P\&O Ports } 49 \% \text {, Qingdao Port } \\
\text { Authority } 51 \% \\
\text { Conaust (P\&O subsidiary) } 22.5 \% \text {, } \\
\text { Gerrbulk } \\
\text { Shipping } 22.5 \% \text {, Tianjin Port Authority } \\
55 \% \\
\text { Pacific Ports 24.5\%, CSX World } \\
\text { Terminals } 24.5 \% \text {, Tianjin Port Authority } \\
51 \%\end{array}$ \\
\hline
\end{tabular}

Source: Based on Wang et al. (2003) 
Table 8. Container port construction projects in China as of December 2005

\begin{tabular}{|c|c|c|c|c|c|}
\hline Port & Operator & Investment & Specificities & Capacity & Schedule \\
\hline Qingdao & DP World & $\$ 500 \mathrm{~m}$ & 4 berths, $1320 m$ & $2 \mathrm{~m}$ TEU & $2008 / 2009$ \\
\hline Qingdao & SITC Group & undisclosed & 2 berths, $438 m$ & & 2009 \\
\hline Qingdao & China Merchants & $\$ 556 \mathrm{~m}$ & $6+2$ berths, $2272 m$ & $2.5 \mathrm{~m}$ TEU & 2010 \\
\hline Tianjin & PSA International & $\$ 200 m$ & 6 or 7 berths, $2200 \mathrm{~m}$ & & 2010 \\
\hline Tianjin & $\begin{array}{l}\text { Tianjin Wuzhou Intern. Container Terminals } \\
\text { Cosco Pacific, China Shipping } \\
\text { China Merchants, NSW Holdings }\end{array}$ & $\$ 319 m$ & 4 berths, $1202 m$ & 1.5m TEU & shortly \\
\hline Dalian & $\begin{array}{l}\text { Dalian Port Container Terminal } \\
\text { Cosco Pacific, PSA International } \\
\text { APM Terminals, Dalian Port Container co. }\end{array}$ & undisclosed & $\begin{array}{l}\text { berths } 11-16,2097 \mathrm{~m} \\
13.5-17.8 \mathrm{~m} \text { draft }\end{array}$ & $2.8 \mathrm{~m}$ TEU & operational \\
\hline Nanjing & $\begin{array}{l}\text { Nanjing Longtan Container Terminal } \\
\text { Cosco Pacific \& local partners }\end{array}$ & $\$ 100 m$ & $\begin{array}{l}5 \text { berths, } 910 m \\
12 m \text { draft }\end{array}$ & $1 \mathrm{~m}$ TEU & operational \\
\hline Ningbo & $\begin{array}{l}\text { Ningbo Beilun Phase IV - berth } 7 \\
\text { Cosco Pacific, OOCL, Ningbo Port Group }\end{array}$ & $\$ 140 m$ & 1 berth & $0.4 \mathrm{~m}$ TEU & mid 2006 \\
\hline Ningbo & $\begin{array}{l}\text { Ningbo Beilun Phase IV - berth } 5 \& 6 \\
\text { Ningbo Port Group, Lloyd Triestino }\end{array}$ & $\$ 250 \mathrm{~m}$ & 2 berths & $1 \mathrm{~m}$ TEU & mid 2006 \\
\hline Ningbo & $\begin{array}{l}\text { Ningbo Beilun Phase II } \\
\text { Hutchison, Ningbo Port Group }\end{array}$ & $\$ 121 \mathrm{~m}$ & undisclosed & $1 \mathrm{~m}$ TEU & mid 2006 \\
\hline Ningbo-Zhoushan & Zhoushan Yongzhou Container Terminal & & 6 berths & & start 2007 \\
\hline Ningbo-Zhoushan & Jintang Container Terminals phase 1 & & 5 berths & & start 2007 \\
\hline Shanghai & $\begin{array}{l}\text { Yanshan Deepwater port - phase I } \\
\text { Shanghai International Port Group } \\
\text { Shanghai Container Holding }\end{array}$ & & 5 berths & $3 m$ TEU & operational \\
\hline Shanghai & $\begin{array}{l}\text { Yanshan Deepwater port - phase II } \\
\text { APMTerminals, Hutchison, Shanghai Port } \\
\text { Group, Cosco Pacific, China Shipping }\end{array}$ & & 4 berths, $1400 m$ & 2.4m TEU & late 2006 \\
\hline Shanghai & Yanshan Deepwater port - later phases & & Yangshan: total 52 berths & 20m TEU & 2020 \\
\hline Guangzhou & $\begin{array}{l}\text { Guangzhou Nansha CT Phase II } \\
\text { Cosco Pacific }\end{array}$ & $\$ 483 m$ & $\begin{array}{l}6 \text { berths, } 2100 m \\
17 m \text { draft }\end{array}$ & $4.2 \mathrm{~m}$ TEU & mid 2006 \\
\hline Shenzhen & $\begin{array}{l}\text { Shenzhen Yantian Port Expansion } \\
\text { Hutchison, Yantian Port Group }\end{array}$ & $\$ 1238 m$ & 6 berths, $3027 \mathrm{~m}$ & undisclosed & $2006-2010$ \\
\hline Shenzhen & China Merchants & $\$ 62 m$ & $\begin{array}{l}\text { Cosco Pacific sells } 17 \% \\
\text { stake in Shekou Terminals }\end{array}$ & $n / a$ & operational \\
\hline Hong Kong & PSA International & $\$ 387 m$ & $\begin{array}{l}\text { NSW Holdings sells equity } \\
\text { stakes in CT3 and CT8 }\end{array}$ & $n / a$ & operational \\
\hline Hong Kong & China Merchants & $\$ 373 m$ & $\begin{array}{l}\text { Swire Holdings sells } 17 \% \\
\text { stake in MTL }\end{array}$ & $\mathrm{n} / \mathrm{a}$ & operational \\
\hline Hong Kong & PSA International & $\$ 925 m$ & $\begin{array}{l}\text { Hutchison sells } 20 \% \text { HIT } \\
\text { stake } \& 10 \% \text { HIT-Cosco stake }\end{array}$ & $n / a$ & operational \\
\hline
\end{tabular}

Source: Van Marle (2005) and press releases

\subsection{Serving East Asia via the Korean Twin Hub System}

The Korean container port system is in fact a 'twin hub system' based on Busan and Gwangyang. These ports have shown substantial growth in container throughput and transhipment, and attracted new investments from several major private terminal operators. The Korean port Busan and to some extent also newcomer Gwangyang traditionally play an important role in Northeast Asia, especially in relation to Japan and the North-Eastern Chinese ports. Transhipment accounted for some 36\% of the 12 million containers handled in the Korean ports in 2003. Chinese transhipment boxes 
represent some $30 \%$ of total sea-sea transhipment volumes (56\% in Gwangyang and 30\% in Busan, figures Korea Container Terminal Authority).

Transhipment cargo is expected to increase every year. However, given the increasing direct calls at the load centre ports of Northeast China, it is not unlikely that the share of Chinese traffic in the overall traffic would stabilize at around $10 \%$. Given the strong expected growth of Chinese containerised trade in the coming decades, this would result in a relative decline in the importance of Korean ports in relation to China.

\subsection{Shanghai: the New Transhipment Hub?}

The world's top twenty shipping companies have all set up business in Shanghai. Total container throughput reached 18 million TEU in 2005. To manage this, the Shanghai Port Authority has converted general cargo terminals into container terminals, building dedicated container terminals at the Waigaoqiao area. Efforts are also being made to build the Waigaoqiao area into a procurement and distribution centre for the Asia Pacific Region.

The capacity problem and the lack of deep-water berths is further solved by the construction of a new deep-water port (see also Table 8). The Chinese authorities are constructing a new port with 52 berths and a capacity of 20 million TEU in 2020 at the Yangshan islands, $100 \mathrm{~km}$ south of Shanghai and $30 \mathrm{~km}$ offshore. A bridge of $32.2 \mathrm{~km}$ connects the port with the mainland. With the opening of phase one in December 2005, which consists of 5 berths and a capacity of 3 million TEU, the pressure on Shanghai Port is diminished.

The Shanghai port is building its own domestic and international transport network so as to become the container transhipment centre of China. A high frequency service between the port of Shanghai and the three main Northeast ports would make transhipment between these ports possible. Transhipments will incur some additional container handling costs. The estimated cost to handle one container in Shanghai is between US\$ 30-40, significantly lower than the US\$ 200 in Hong Kong. The handling costs in Shanghai port are lower than in Hong Kong and Singapore, while in practice the total bill for shippers and carriers is not that low, because of extra charges incurred for other procedures. These extra charges mainly relate to administrative regulations, on-dock transfer and container inspection. This factor constitutes an important barrier to Shanghai while competing with other ports. Shipping lines require transparency of 
charges when selecting their ports of call. A transparent port charging system needs to be in place, so as to sustain the port's competitive position, in particular in view of developing sea-sea transhipment.

Taking advantage of its geographical location, Shanghai strives to consolidate its position as a pivot in an emerging domestic container shipping network with 40 other ports from the north to the south of China. With a solid basis for developing the Shanghai port into a transhipment hub already in place, Shanghai port still faces many challenges, such as government support, competition from ports of northern China and the integration problem of Waigaoqiao and Yangshan ports. Fierce competition exists between the ports of Dalian, Qingdao, Tianjin, Shanghai and Ningbo. All these ports achieved astonishing growth rates in container throughput last year, while competition is dominant over co-operation when it comes to inter-port relations. The ports considered are mainly concerned about their own performance instead of the optimisation of the port system of the whole region. The efforts made by these ports are derived from their own profits and development concerns, while some steps might be harmful for the integration of the whole system. This situation surely makes transhipment to northern ports of China more difficult since these ports are endeavouring to compete with Shanghai for attracting direct calls of mainline vessels. The port of Ningbo serves as an example: it competes with Shanghai in attracting containers from the Yangtze River Delta because of the close proximity to Shanghai. Growth at Ningbo meant a volume loss at Shanghai. Shanghai used to negotiate with Ningbo for supporting the Yangshan port construction and to switch its main focus on bulk instead of container. Ningbo port rightly complained that the profit of bulk handling is far less than container. Eventually, the competitive situation intensified rather than weakened.

\section{CONCLUSIONS}

This paper sheds light on the container port system in East Asia. The paper not only assessed inequality at the level of the entire port system but also the individual port ranges. Using the Gini decomposition analysis technique as developed by Dagum, relevant observations could be made with respect to e.g. the net contribution of the inequality between a distinctive range pair to overall traffic concentration in a port system.

The inequality between the East Asian ranges explains more than half of the Gini values for the entire container port system. In geographical terms this means that the 
observed traffic concentration levels in the East Asian container port system are emanating from inter-range structural differences. Nearly all port ranges fully participate in international shipping networks and each port range consists of a unique blend of load centre ports and smaller facilities with a more local focus. The results also provide a good basis for assessing the effects of recent changes in liner service schedules, hinterland services and market organisation (e.g. in the logistics industry and liner shipping) on the spatial dispersion of container handling activities.

Containerization in the region is largely encouraged by recent port reform measures, trade liberalisation and the economic boom of China. China exerts a considerable effect on the liner shipping market, not the least because of the existing trade imbalances caused by the large export flows out of China. The future prospects of China's shipping industries are very promising as the regulatory and economic climates are becoming more favourable and open.

Against the background of the Chinese economic boom, the traditional port hierarchy in the region is losing ground to a new dynamic development including more direct calls to emerging Chinese gateway ports. In the coming decades, shipping lines will predominantly serve container ports in China by means of direct calls with mainline vessels, and not by indirect (feeder) calls. Due to the huge cargo generating capacity of the Bohai Bay, the Yangtze River Delta and the Pearl River Delta shipping lines increasingly include direct calls to these ports in their loops, notwithstanding considerable deviation distances for their mainline vessels. The possibility for the Shanghai port to become the transhipment center in Northeast China remains uncertain, partly because of fierce competition and weak co-operation with other Northeast ports and Korean ports. 


\section{REFERENCES}

Barke, M., 1986, Transport and Trade. Oliver \& Boyd: Edinburgh

Dagum, C., 1980, "Measures between Income Distribution with Applications," Econometrica, 48, 1791-1803

Dagum, C., 1997, “A New Decomposition of the Gini Income Inequality Ratio," Empirical Economics, 22(4), 515-31.

De, P. and Park, R. K., 2004, "International Container Port System Concentration : What Does it Look Like ?" Journal of International Logistics and Trade, 2(1), 95-118

Fleming, D., 1997, “World Container Port Rankings," Maritime Policy and Management, 24(2), 175-182

Guo, H. and Notteboom, T., 2004, "Container Flows to Northeast China: Sea-Sea Transhipment versus Direct Port Calls," Proceedings of the First International Conference on Logistics Strategy for Ports, Dalian Maritime University Press, Dalian (China), 814-829

Hayuth, Y., 1981, "Containerization and the Load Center Concept," Economic Geography 57(2), 160-176

Hayuth, Y., 1988, "Rationalization and Deconcentration of the US Container Port System," The Professional Geographer, 40 (3), 279-288

Kuby, M. and Reid, N., 1992, "Technological Change and the Concentration of the U.S. General Cargo Port System: 1970-1988,” Economic Geography, 68(3), 272-289

Lago, A., Malchow, M. and Kanafani, A., 2001, “An Analysis of Carriers' Schedules and the Impact on Port Selection," Proceedings of the IAME 2001 Conference, Hong Kong, 123-137

McCalla, R., 1999, “From St. John's to Miami: Containerisation at Eastern Seaboard Ports," GeoJournal, 48, 21-28

Mussard, S., Seyte, F. and Terraza, M., 2003, "Decomposition of Gini and the Generalized Entropy Inequality Measures,” Economics Bulletin, 4(7), 1-6

Notteboom, T., 1997, “Concentration and Load Centre Development in the European Container Port System," Journal of Transport Geography, 5 (2), 99-115

Notteboom, T. and Rodrigue, J. P., 2005, "Port Regionalization: Towards a New Phase in Port Development," Maritime Policy and Management, 32(3), 297-313 
Robinson, R., 1998, “Asian Hub/Feeder Nets: the Dynamics of Restructuring,” Maritime Policy \& Management, 25, 21-40.

Taaffe, E.J., Morrill, R.L. and Gould, P.R., 1963, "Transport Expansion in Underdeveloped Countries: A Comparative Analysis," Geographical Review, 53, 503-529

Van Marle, G., 2005, "Cutting Their Losses," Cargo Systems, December, 34-35

Wang, J.J., 1998, “A Container Load Center with a Developing Hinterland: A Case Study of Hong Kong,” Journal of Transport Geography, 6(3), 187-201

Wang, J., Ng, A. and Olivier, D., 2003, "Port Governance in China: A Review of Policies in an Era of Internationalizing Port Management Practices," Transport Policy, November

Yap, W.Y., Lam, J.S.L. and Notteboom, T., 2006, "Developments in Container Port Competition in East-Asia," Transport Reviews, 26(2), 167-188 